\title{
Export Contribution of Micro, Small and Medium Enterprises to GDP Per capita in Indonesia
}

\author{
Deddy Tri Harjanto ${ }^{1}$, Cicih Ratnasih ${ }^{1} \&$ Yolanda $^{1}$ \\ ${ }^{1}$ Borobudur University, Indonesia \\ Correspondence: Cicih Ratnasih, Borobudur University, Indonesia.
}

Received: December 3, 2021; Accepted: December 18, 2021; Published: December 19, 2021

\begin{abstract}
This study will determine how much the influence of the exchange rate, the number of MSMEs, investment, credit, and inflation on MSME exports nationally, and how they contribute to GDP per capita. The research method uses multiple regression with data transformation $\ln$. The results of the study consist of model 1 , the exchange rate factor, the number of MSMEs, investment, credit, and inflation are variables that influence increasing the number of product exports produced from the MSME sector. In the second model, the contribution of MSME exports to GDP per capita. The results showed that of all significant positive variables and one significant negative variable. The investment required in Indonesia, whose number continues to increase yearly, affects the high number of products exports from the MSME sector.

For this reason, investment factors must continue to be considered to increase MSME exports. In contrast, the contribution of the inflation variable has a significant negative effect, which is an inverse relationship to MSME exports. It is predicted that if inflation is low, MSME exports will increase, and vice versa if inflation is high, MSME exports will decline. Furthermore, model 2 shows that MSME exports significantly contribute to gross domestic product per capita. In this case, the ups and downs of Micro, Small, and Medium Enterprises' exports need special attention.
\end{abstract}

Keywords: exchange rate, Number of MSMEs, Investment, Credit, Inflation, National Exports and GDP per capita

\section{Introduction}

The existence of small businesses of the Indonesian people is highly expected; therefore, it cannot be eliminated or avoided. Small business is a place to create creativity that is in line with developing entrepreneurial habits to increase income. Small businesses can absorb such a large number of workers, which can reduce the unemployment rate, which has always been a problem in Indonesia. Efforts to develop small businesses have become a local tradition and culture in Indonesia, considering Indonesia has a large population, including Southeast Asia.

In principle, the distinction between Micro, Small, and Medium Enterprises is based on the initial asset value (excluding land and buildings), the average annual turnover, or the number of permanent employees. This business creation can be seen in various kinds of foods such as; snack cakes, necessities at the stalls, handicrafts, and entrusting children to playgroups. As for the current digital era, the results of these business creations are increasing because the activities do not require a place; even shops and only market their products online do not yet have a business license.

Table 1 is about the development of micro, small and medium enterprises in Indonesia during the last five years from 2014 to 2018.

Table 1. Development of MSMEs in $2014-2018$

\begin{tabular}{llllllll} 
Year & $\begin{array}{l}\text { Number of SMEs } \\
\text { (Units) }\end{array}$ & $\begin{array}{l}\text { Micro business } \\
\text { (Units) }\end{array}$ & Share (\%) & $\begin{array}{l}\text { Small business } \\
\text { (Units) }\end{array}$ & $\begin{array}{l}\text { Share } \\
(\%)\end{array}$ & $\begin{array}{l}\text { Medium Enterprise } \\
\text { (Units) }\end{array}$ & $\begin{array}{l}\text { Share } \\
(\%)\end{array}$ \\
2014 & 57.895 .721 & 57.189 .393 & 98,77 & 654.222 & 1,13 & 52.106 & 0,09 \\
2015 & 59.262 .772 & 58.521 .987 & 98,74 & 681.522 & 1,15 & 59.263 & 0,10 \\
2016 & 61.651 .177 & 60.863 .578 & 98,71 & 731.047 & 1,19 & 56.551 & 0,09 \\
2017 & 62.992 .617 & 62.106 .900 & 98,70 & 757.090 & 1,20 & 58.627 & 0,09 \\
2018 & 64.194 .057 & 63.350 .222 & 98,68 & 783.132 & 1,22 & 60,702 & 0,09 \\
\hline
\end{tabular}

Source: Ministry of Cooperatives and Small and Medium Enterprises, SMEs, 2019 
The productivity of Micro Enterprises is still much lower than that of Small and Medium Enterprises, which makes them generally more fragile and may easily collapse due to competitive pressures. Like it or not, there must be embedded and structured assistance so that Micro Enterprises can improve production efficiency, productivity, and resilience in the face of competition. On the other hand, micro-enterprises also need to open up to new technologies, especially in utilizing various digital solutions to expand the market while reducing various production costs.

According to the Decree of the Minister of Industry and Trade Number 182/MPP/Kep/4/1998 concerning General Provisions in the Export Sector, the definition of export is the activity of removing goods and services from the customs area of a country. The customs area is defined as the territory of the Republic of Indonesia, which includes land, waters, and air space above it and certain places in the exclusive economic zone and continental shelf in which Law No. 10 of 1995 concerning Customs applies.

Concerning efforts to encourage MSMEs to go international, MSME products must have enormous potential to penetrate the export market. Exports are various kinds of goods and services produced domestically and then sold abroad (Rajput et al., 2012). In terms of expenditure, exports are one of the most important factors of Gross National Product (GNP), so that with changes in the value of exports, people's incomes will directly experience changes. On the other hand, the high exports of a country will cause the economy to be very sensitive to shocks or fluctuations that occur in the international market and the world economy (Akalpler, 2013).

By exporting, MSME actors have the potential to get greater profits because the market will become wider. However, many do not know and understand the procedures and mechanisms that must be followed so that their products can be exported abroad. By entering the global market, MSMEs benefit from opening access to new customers that can increase revenue and growth in the long term, given the large market faced by MSMEs. For that, of course, MSMEs must be able to improve the competitiveness of the company through improving product quality according to customer desires. This condition becomes a note that forms the basis for why MSMEs must export.(Dincer \& Kandil, 2011), this export requirement is because the potential of the export market is far greater than the potential of the domestic market, which is also quite large and involves at least 269 million people.

MSME exports always see the movement of the rupiah exchange rate; this is because it is related to export costs. Many factors underlie this assessment, especially the exchange rate value during the monetary crisis 22 years ago, which weakened the rupiah's value against the US dollar, so the resilience of the MSME sector is still remembered because it was able to survive amid the crisis.

When other sectors collapse, this is not the case with the MSME sector. The Center for Information-Development Studies (CIDES) notes that three factors make the sector able to survive.

The three are closely related to each other. In addition to the rupiah exchange rate factor, the growth in the number of MSMEs itself has the biggest role in encouraging the export of MSME products. The number of Indonesian MSME industry business actors is the largest among other countries, especially since 2014 . The number of MSMEs in Indonesia continues to experience growth from 2015, 2016 to 2017. The number of MSME actors in Indonesia will continue to experience growth. In recent years, the population of productive age has been more than the number of available jobs. It triggers especially the youth to create their opportunities by opening a business. Most of them are classified as business actors in the Micro, Small, and Medium Enterprises (MSME) industry sector.

Micro, small and medium enterprises (MSMEs) must be viewed as investors, not just large and foreign investors. This MSME investment is still dominated by domestic or PMDN investment, and only a small portion of foreign investment is in medium-sized businesses.

Moreover, this country still needs big investments,(Zulher \& Ratnasih, 2021). MSME loans were still more focused on the wholesale and retail trade sector $(50.39 \%$ ), which slowed to $5.43 \%$ (YoY) compared to $7.89 \%$ (YoY) in the previous year, thus pulling down the total MSME loan growth.

The Government's desire for banks to boost MSME loans is understandable. Nevertheless, on the other hand, it should also be realized that the essence of the banking business is trust services.

The stability of the inflation rate is very important to support people's economic activities. If the level or condition of inflation is stable, it can lead to public confidence in carrying out both consumption and investment activities.

Significant fluctuations in inflation will disrupt the stability of the economy. The impact of high inflation will be detrimental to many groups of people, especially the income of MSMEs. 
Inflation can have a negative or positive effect on exports. The negative effect of inflation is that when inflation occurs, commodity prices will increase. The increase in commodity prices is due to production to produce commodities that cost much money.

\section{Theory}

Economic growth is the dream of every country in the world. However, the expected economic growth must usually be followed by stability, economic justice, and even income distribution in every region in the country. In addition, the increase in human population and unlimited needs encourage the economy always to increase the production of goods and services and will increasingly allow the increase in the number of workers absorbed in producing these goods. So that economic growth will occur in the country, and it will be better if followed by an even distribution of growth. According to Bank Indonesia, a small business is a productive business owned by an Indonesian citizen.(Zulher \& Ratnasih, 2021)

In the form of an individual business entity, a business entity that is not a legal entity, or a business entity with a legal entity such as a cooperative; is not a subsidiary or branch that is owned, controlled, or affiliated, either directly or indirectly with a medium or large business.

Developing countries are starting to change their orientation when they see experiences in developed countries regarding the role and contribution of MSMEs in economic growth. Micro, small and medium enterprises play important roles in economic development and growth in developing countries and developed countries. In developed countries, MSMEs are very important because these business groups absorb the most labor compared to large businesses. In developing countries, especially Asia, Africa, and Latin America, MSMEs also play a very important role, especially from employment opportunities and sources of income for the poor, income distribution, and poverty reduction. As well as rural economic development, (Gounder \& Sharma, 2012) added that when viewed from its contribution to Gross Domestic Product (GDP) and Non-Oil and Gas Exports, specially manufactured products, and innovation and technological development, the role of MSMEs in developing countries relatively low, and this is the most striking difference with MSMEs in developed countries.

Trade between countries, better known as international trade, has existed since ancient times, but in a limited scope and quantity, where the fulfillment of local (domestic) needs that cannot be produced, they carry out transactions by barter (exchange of goods for goods). Other goods are needed by both parties, where each country cannot produce the goods for its own needs).(Dincer \& Kandil, 2011). It happens because each country and its trading partner countries have several differences, including differences in the content of natural resources, climate, population, human resources, labor specifications, geographical configuration, technology, price levels, economic structure. Social and political and so on. From these differences, then based on mutually beneficial needs, an exchange process that on a broad scale is known as international trade in the direction of(Flatten et al., 2011).

Export is trade by removing goods from within and outside the country by complying with applicable regulations. A country's exports occur because of the benefits derived from foreign trade transactions. Trade can also increase the consumption capacity, help various businesses carry out development, and increase the role of sectors that have a comparative advantage due to efficiency in factors of production. Exports are various kinds of goods and services produced domestically and then sold abroad (Mahmoodi \& Mahmoodi, 2016).

In terms of expenditure, exports are one of the most important factors of Gross National Product (GNP), so that with changes in the value of exports, people's incomes will directly experience changes. On the other hand, the high exports of a country will cause the economy to be very sensitive to shocks or fluctuations that occur in the international market and the world economy.(Flatten et al., 2011). According to the Central Bureau of Statistics version, all goods are brought out of a country's territory.

Both commercial and non-commercial (grants, donations, gifts) and goods to be processed abroad, and the results are returned to the country. As for what is not included in the export category, clothing, personal items and jewelry belonging to passengers traveling abroad, goods sent for representatives of a country abroad, goods for expeditions/exhibitions, containers to be refilled, money and securities, and goods for example

Export is legally transporting goods or commodities from one country to another, generally in the trade process. Many economists consider international trade as a balance of internal production capabilities with domestic demand. If the people of a country demand more of a certain product than its production capacity, then the shortage will be filled by importing it. Likewise, the occurrence of exports, if the amount of consumption of the product produced is getting smaller, it means that the excess is a product that can be exported. ((Mankiw, 2003)). Thus, export is one of the economic activities carried out by selling or removing goods from within the country and sent to other countries. Usually, this trade is carried out when a country produces these goods in large quantities. 
Domestic capital is an investment activity to invest or do business in the territory of the Republic of Indonesia carried out by domestic investors using domestic capital as regulated by the provisions of Article 1 of Law No. 25 of 2007 concerning Investment. Domestic capital is capital owned by the Republic of Indonesia, individual Indonesian citizens, or business entities in the form of legal entities or not legal entities. The private party that owns the Domestic Capital can be an individual or a legal entity established under the laws in force in Indonesia.

Domestic Investment or Investment (DI) is the use of wealth as mentioned above, either directly or indirectly, to run a business according to or based on the provisions of the Investment Law. Direct use of wealth is the use of capital used directly by domestic investors for business development, while indirect use is the use of capital that is not used directly to build a business. The implementation of the investment is based on the applicable laws and regulations.

According to (Patty \& Kuncoro, 2016), adherents of an open economic system, international trade traffic plays an important role in the economy and development in Indonesia is how far the role of foreign trade can be seen from the ratio between exports plus imports to GDP.

According to customs, export is the activity of removing goods from the customs area. Customs area is the territory of the Republic of Indonesia, which includes land, waters, and air space above it and certain places in the Exclusive Economic Zone and Continental Shelf in which the Customs Law applies. According to Todaro (2014), exports are international trade activities that provide a stimulus to grow domestic demand, leading to the growth of large manufacturing industries and a stable political structure and flexible social institutions. In other words, exports reflect international trade activities so that a developing country is likely to achieve economic progress on par with more developed countries.

GDP per capita, which is the magnitude of GDP when compared to the total population in a country, is a better tool that can tell us what is happening to the average population, the standard of living of its citizens (Mankiw, 2003), GDP (capita) seems to be a fairly natural measure of average individual well-being. GDP per capita tells us what happens to the average population, but there are vast differences between people's experiences behind these averages. In the end, we can conclude that GDP is a good measure of well-being for many purposes, but not for all purposes. According to (Mankiw, 2003). said that per capita income also has several benefits, including an indicator of state welfare, growth standards of state prosperity, as a guide for the government in making economic policies, and comparing levels of prosperity between countries.

\section{Methods}

The data used in this study is time-series data; if viewed from its nature, it is quantitative data, namely secondary and measurable data, in the form of quarterly reports. In addition, the researchers also collected some secondary data related to the theme of this research at the Central Bureau of Statistics Jakarta, the Ministry of Cooperatives and SMEs, Bank Indonesia, the Ministry of Trade, the Ministry of Industry, the Ministry of Manpower \& Transmigration.

The natural logarithm transformation is used in situations where there is a non-linear relationship between the explanatory and dependent variables.

The logarithmic transformation will make non-linear relationships usable in linear models. In addition, logarithmic transformation can change data that is initially distributed deviate or not normally distributed to or close to a normal distribution.

Data analysis techniques used in this study are inferential statistics and regression analysis, because I want to know how much influence the independent variable to dependent variable.

The research method, according to the level of explanation of this research, is associative research. Associative research is research that aims to determine the relationship between two or more variables.

A regression equation is good if the equation is linear and where the equation meets the BLUE (Best Linear Unbiased Estimation) assumption. The research model uses causality between the independent variables and the dependent variable. The theorem of agreement in this study can be explained in the following formulation:

\section{Multiple linear regression equation:}

Model 1: $Y=\beta_{0}+\beta_{1} X_{1}+\beta_{2} X_{2}+\beta_{3} X_{3}+\beta_{4} X_{4}+\beta_{5} X_{5} E$

Model 2: $Z=\beta_{0}+\beta_{1} Y+E$

The Ln transformation as follows:

Model $1=\ln \_Y=\beta_{0}+\beta_{1} \ln \_X_{1}+\beta_{2} \ln \_X_{2}+\beta_{3} \ln \_X_{3}+\beta_{4} \ln \_X_{4}+\beta_{5} \ln \_X_{5}+E$ 
Model 2: $\ln \mathrm{Z}=\beta_{0}+\beta 1 \ln \mathrm{Y}+\mathrm{E}$

Information:

$\ln Z=$ Income Per capita

$\ln \mathrm{Y}=$ Export of MSME Products

$\ln \mathrm{X} 1=$ Exchange Rate

$\ln \mathrm{X} 2=$ Investment growth

$\ln \mathrm{X} 3=$ Investment

$\ln \mathrm{X} 4=$ Credit

$\ln \mathrm{X} 5=$ Inflation

A good research model is required to meet the characteristics specified in an econometric model (the goodness of an econometric model). Following (Gujarati, 2014) and with the condition that the results of the model feasibility test show that the research model has met the goodness of an econometric model or the typical characteristics, as follows:

Theoretical Plausibility; Testing This research model shows whether the test results are under expectations from the economic theory as the basis for thinking.

Accuracy of The Estimate of The Parameters; Measuring whether this research model produces an accurate or unbiased and significant regression coefficient estimator. The analysis assumption is met if the probability of statistical error from the model is very low ( $\mathrm{p}$-value $=0.05$ or less than (alpha).

Explanatory Ability; The research model can explain the relationship between the economic phenomena studied.

Standard error of estimates (SE) is where variance error of estimates $=\mathrm{SE} 2<$ mean square of regression in the Anova table.

This research used Forecasting Ability; Testing whether the model will have a high predictive ability on the behavior of the dependent variable. The criterion is if the high coefficient of determination of the model approaches or exceeds $50 \%$.

\section{Results and Discussion}

The following are descriptive statistics on income per capita for 2010 to 2020 obtained from the Central Statistics Agency;

Table 2. Descriptive Statistics of Income Per Capita in the Year 2010 - 2020 (In Quarter)

\begin{tabular}{lll}
\hline DESCRIPTIVE & VALUE (Rupiah) & QUARTER/YEAR \\
\hline Average & $43.051 .619,00$ & \\
The highest value & $62.244 .120,00$ & Quarter IV / 2020 \\
The lowest value & $24.866 .399,41$ & Quarter I / 2010 \\
Standard Deviation & $11.300 .838,86$ & \\
Average Growth & $2,48 \%$ & \\
The Highest Growth & $9,32 \%$ & Quarter I / 2019 \\
The Lowest Growth & $0,65 \%$ & Quarter I / 2016 \\
\hline
\end{tabular}

Source: Central Bureau of Statistics, 2020

Table 2 shows that the number of observations studied of 44 samples.

Income Per Capita has an average value of Rp. 43,051,619 with the Highest Per Capita Income of Rp. 62,244,120 occurred in the fourth quarter of 2020, and the lowest Per Capita Income was Rp. 24,866,399.41. In the first quarter of 2010, with a standard deviation or an average deviation value Rp. 11,300,838,86.

The highest per capita income occurred in the fourth quarter of 2020, in line with the increase in GDP in the same period. Indonesia's GDP per Capita has increased rapidly in the 2000s and after.

Initially, the World Bank projected that Indonesia would reach USD 3,000 (per Capita) by 2020, but the country has reached this level a decade earlier. Achieving a GDP per Capita level of USD 3,000 is considered an important step. 
It should lead to accelerated development in several sectors (such as retail, automotive, property) due to increased consumer demand and thus become a catalyst for economic growth.

The following are Descriptive Statistics of Indonesian MSME Product Exports in the period 2010 to 2020 obtained from the Central Statistics Agency:

Table 3. Descriptive Statistics of Indonesian MSME Product Exports Year 2010-2020 (In Quarter).

\begin{tabular}{lrr}
\hline DESCRIPTIVE & Value (Billion Rupiah) & QUARTER/YEAR \\
\hline Average & $228.558,17$ & \\
The highest Value & $329.446,27$ & Quarter IV / 2019 \\
The lowest Value & $149.971,83$ & Quarter I / 2010 \\
Standard Deviation & $63.176,99$ & \\
Average Growth & $1,83 \%$ & \\
The Highest Growth & $28,44 \%$ & Quarter I / 2016 \\
The Lowest Growth & $-6,78 \%$ & Quarter IV / 2013 \\
\hline
\end{tabular}

Source: Ministry of Cooperatives \& SMEs,2020

Indonesian MSME products have an average value of Rp. 228,558.17 billion with the highest export value of Indonesian MSME Products of Rp. 329,446.27 billion occurred in the fourth quarter of 2019, and the lowest Indonesian MSME Product Export of Rp. 149,971.83 billion in the first quarter of 2010, with a standard deviation or average deviation value of Rp. 63,176.99 billion.

In 2019 the export of MSME products reached the highest value for the last 11 years, with the export value of MSME products reaching Rp. 329,446.27 billion. Throughout 2019, MSMEs contributed 60.34 percent of GDP and contributed 14 percent of total national exports.

In 2019, several MSME business sectors became the mainstay of exports amid challenging economic conditions. These include the culinary, fashion, and handicraft sectors. These sectors can survive because they use domestic raw materials that can reduce costs. (Rosyadi \& Ratnasih, 2021).

Meanwhile, at the beginning of 2010, the export value was so low due to several things such as the weak ability of MSMEs to meet anticipated market demand, then, weak skills in conducting online trading, and lack of access to administrative support for exporting, as in the paper (Gounder \& Sharma, 2012).

The following is descriptive statistical data on the growth of the number of MSMEs in Indonesia for the period 2010 to 2020 obtained from the Ministry of Cooperatives and SMEs:

Table 4. Descriptive Statistics of Growth in the Number of MSMEs 2010 - 2020 (In Quarter)

\begin{tabular}{lrc}
\hline DESCRIPTIVE & Value Percentage & QUARTER/YEAR \\
\hline Average Growth & $0,93 \%$ & \\
The Highest Growth & $6,03 \%$ & QUARTER I / 2020 \\
The Lowest Growth & $0,14 \%$ & QUARTER II / 2013 \\
Standard Deviation & $0,98 \%$ & \\
\hline
\end{tabular}

Source: Ministry of Cooperatives \& SMEs,2020

Table 4. shows the number of observations studied of 44 samples. Growth in the number of MSMEs has an average value of 0.93 percent with the highest growth value of 6.03 percent in the number of MSMEs occurring in the first quarter of 2020 and the lowest growth in the number of MSMEs at 0.14 percent in the second quarter of 2013, with a standard deviation is 0.98 percent.

In the first quarter of 2020, it was the highest growth achieved in the number of MSMEs in Indonesia before the COVID-19 pandemic hit Indonesia.

The development of micro, small and medium enterprises in Indonesia at that time could not be separated from the factors that drove this progress (Flatten et al., 2011), (Thomas Katua, 2014), (Katua, 2014). 
According to several views and research, several factors encourage the advancement of the development of MSMEs in Indonesia, including ICT facilities (technology, information, and communication). Business actors have begun to take advantage of technological means such as smartphones to expand their business market and use communication applications such as WhatsApp and social media to market the products they sell.

In addition, the opening of access to bank financing and the decline in people's business loans have encouraged the growth of micro, small and medium enterprises. The nominal capital for starting a business, especially microenterprises, is considered not too large so that anyone can quickly become an MSME actor.

The Descriptive Statistics of Investment in the MSME sector for the period 2010 to 2020 obtained from the Ministry of Cooperatives and SMEs:

Table 5. Descriptive Statistics of Investment in the MSME sector 2010 - 2020 (In Quarter)

\begin{tabular}{lrr}
\hline DESCRIPTIVE & VALUE (Billion Rupiah) & QUARTER/YEAR \\
\hline Average & $858.484,16$ & \\
The Highest Value & $1.768 .277,36$ & Quarter IV / 2019 \\
The Lowest Value & $216.692,58$ & Quarter I / 2010 \\
Standard Deviation & $645.902,34$ & \\
Average Growth & $7,95 \%$ & \\
The Highest Growth & $263,28 \%$ & Quarter I / 2016 \\
The Lowest Growth & $-12,19$ & Quarter II / 2020 \\
\hline
\end{tabular}

Source: Ministry of Cooperatives \& SMEs,2020

Table 5. shows that the number of observations studied of 44 samples. MSME sector investment has an average value of $\mathrm{Rp}$. 858,484.16 billion with the highest investment value of Rp. 1,768,277.36 trillion occurred in the fourth quarter of 2019, and the lowest investment was Rp. 216,692.58 billion in the first quarter of 2010, with a standard deviation or average deviation value of Rp. 645,902,34.

The fourth quarter of 2019 is the best moment for investment in the MSME sector to boost the export performance of MSME products. The factor that caused the high investment at that time began with the issuance of Presidential Instruction No. 7 of 2019 concerning the Acceleration of the Ease of Doing Business. Now the Indonesian people can register their businesses practically. (Rosyadi \& Ratnasih, 2021).

The Investment Coordinating Board has also facilitated it with the Online Single Submission (OSS) system. The synergy between the Investment Coordinating Board and the Ministry of Cooperatives and SMEs is expected to encourage people further to dare to be entrepreneurship while supporting the development of existing SMEs and cooperatives to rank up. This synergy aims to connect the right investors with the right MSMEs and cooperatives.

The MoU regulates the facilitation of investor matchmaking through seminars, business forums, market sounding, and visits. (Ratnasih, 2018).

The Investment Coordinating Board and the Ministry of Cooperatives and SMEs also focus on standardizing products and marketing by MSMEs and cooperatives. The following are the results of the multiple regression model testing data as follows:

$$
\begin{array}{cccc}
\operatorname{Ln} \mathrm{Y}=\quad 12,33056 & +0,334090 \text { exchange } & +1,243005 \text { lnSMEs } & +0,254827 \text { lnInvest } \\
(2,725544) & (3,618560) & (10,11872) \\
+1,175258 \text { lncredit } & -0,298916 \text { lninflation } & +\mathrm{e} \\
(3,492862) & (-2,416029) &
\end{array}
$$

In the interpretation of economics, the results illustrate that the five variables together contribute to encouraging the increase in Indonesian MSME Product Exports with a coefficient of determination of 26.70 percent. It shows that the combination of the five determinants is a variable that can have a dominant influence on increasing exports of MSME products over the last 11 years.

The inclusion of MSMEs as part of export activities will certainly make the wheels of the economy turn. There are similarities with the research of (Thomas Katua, 2014). It is because the goods produced can be distributed. 
The results of statistical calculations using the multiple linear regression method show that the growth of the number of MSMEs has a significant and positive effect on the export of Indonesian MSME products.

While the significant understanding means that the hypothesis of the Growth of the Number of MSMEs is convincingly and meaningfully can be proven to affect Indonesian MSME Product Exports.

The significance level is expressed in numbers that indicate the possibility or risk of error for the tests carried out, wherein in this study, the number 5 percent or 0.05 was used. The t-test / partial test results resulted in a significance level of 0.0009 or less than 0.005 , which means that the growth of the number of MSMEs has a significant effect on Indonesia's MSME Product Exports. It is in line with research from (Saini \& Raghuveer Singh Rajpurohit, 2014).

The results of statistical calculations using the multiple linear regression method show that investment has a significant and positive effect on Indonesia's MSME Product Exports.

The interpretation in the language of economics has a positive meaning that an increase also follows the increase and investment in Indonesian MSME Product Exports,(Akalpler, 2013). Similar research by (Abdesamed \& Wahab, 2014) Meanwhile, the significant understanding means that the investment hypothesis can be convincingly and meaningfully proven to affect Indonesian MSME Product Exports.

The significance level is expressed in numbers possibility or risk of error for the tests carried out, wherein in this study, the number 5 percent or 0.05 was used.

The t-test / partial test results produce a significance level of 0.0000 or less than 0.005 , which means that investment has a significant effect on Indonesia's MSME Product Exports.

Hypothesis Model Test 2

Partially, the effect of Indonesian MSME Product Exports on Per Capita Income is as follows: Model 2;

$$
\operatorname{Ln} Z=6.275959+0.915793 \ln \text { MSME Expenses }+\mathrm{e}
$$

Based on the results, it concluded that the Effect of Indonesian MSME Product Exports on Income per Capita which obtained in table 7, statistically shows significant results on the probability value of Indonesian MSME Product Exports, which is smaller $=$ than $(0.0000 \leq 0.05)$, it can be concluded that the Indonesian MSME Product Export variable has a significant and positive effect on Income per Capita. This research is in line with (Akoto, 2016).

\section{Conclusion}

1) In model 1, the exchange rate factor, the number of MSMEs, investment, credit, and inflation are variables that have a very conducive contribution to the increasing number of product exports produced from the MSME sector. It can be seen that of all the significant positive variables and there is one negative significant variable. Meaning that these three variables need special attention, so that MSMEs remain a priority.

2) The amount of investment needed in Indonesia continues to increase from year to year which has an effect on the high number of exports of products from the MSME sector, for that investment factor must continue to be considered to increase MSME exports.

3) the contribution of the inflation variable has a significant negative effect, which is an inverse relationship to MSME exports. It is predicted that if inflation is low, MSME exports will increase, and vice versa if inflation is high, MSME exports will decline.

4) In this model 2, it shows that MSME exports have a significant and positive contribution to gross domestic product per capita. In this case, the ups and downs of MSME exports need special attention.

\section{Reference}

Abdesamed, K., \& Wahab, K. A. (2014). Financing of small and medium enterprises (SMEs): Determinants of bank loan application. African Journal of Business Management, 8(17).

Akalpler, E. (2013). Does Inflation Increase the Export? Case Study Turkey. Theoretical and Practical Research in Economic Fields, 4(2). 
Akoto, W. (2016). On the Nature of the Causal Relationships Between Foreign Direct Investment, GDP and Exports in South Africa. Journal of International Development, 28(1). https://doi.org/10.1002/jid.2892

Dincer, N., \& Kandil, M. (2011). The effects of exchange rate fluctuations on exports: A sectoral analysis for Turkey. Journal of International Trade and Economic Development, 20(6). https://doi.org/10.1080/09638190903137214

Flatten, T. C., Greve, G. I., \& Brettel, M. (2011). Absorptive capacity and firm performance in SMEs: The mediating influence of strategic alliances. European Management Review, 8(3). https://doi.org/10.1111/j.1740-4762.2011.01015.x

Gounder, N., \& Sharma, P. (2012). Determinants of bank net interest margins in Fiji, a small island developing state. Applied Financial Economics, 22(19). https://doi.org/10.1080/09603107.2012.674202

Gujarati, D. (2014). Dasar-dasar Ekonometrika. In Dasar-dasar Ekonometrika.

Katua, N. T. (2014). The Role of SMEs in Employment Creation and Economic Growth in Selected Countries. International Journal of Education and Research, 2(12).

Mahmoodi, M., \& Mahmoodi, E. (2016). Foreign direct investment, exports and economic growth: Evidence from two panels of developing countries. Economic Research-Ekonomska Istrazivanja, 29(1). https://doi.org/10.1080/1331677X.2016.1164922

Mankiw, N. G. (2003). Teori Makro Ekonomi Terjemahan. In Jakarta: PT. Gramedia Pustaka Utama.

Patty, R., \& Kuncoro, M. (2016). The linkage between industrialization, urbanization, and tourism: lessons from asean and indonesia. International Journal of Business, Economics and Law, 11(3).

Rajput, N., Rajput, A., Batra, G., \& Oberoi, S. (2012). Relationship of exports, Forex and MSMEs in India: An econometric study. Problems and Perspectives in Management, 10(3).

Ratnasih, C. (2018). Institutional bureaucracy and real sector movement. European Research Studies Journal, 21(4). https://doi.org/10.35808/ersj/1101

Rosyadi, I., \& Ratnasih, C. (2021). The Economic Structure and Employment Opportunities (Cases in Bengkulu, Indonesia). European Journal of Business and Management Research, 6(5). https://doi.org/10.24018/ejbmr.2021.6.5.1074

Saini, B., \& Raghuveer, S. R. (2014). An Empirical Study on Export Financing (Awareness, Impact and Satisfaction) among Handicraft Export Firms in India. Pacific Business Review International.

Thomas, K. N. (2014). The Role of SMEs in Employment Creation and Economic Growth in Selected Countries. International Journal of Education and Research, 2(12).

Zulher, \& Ratnasih, C. (2021). Financial development and poverty reduction in developing countries. Accounting, 7(3). https://doi.org/10.5267/j.ac.2020.12.010

\section{Copyrights}

Copyright for this article is retained by the author(s), with first publication rights granted to the journal.

This is an open-access article distributed under the terms and conditions of the Creative Commons Attribution license (http://creativecommons.org/licenses/by/4.0/). 